1 This manuscript is textually identical with the published paper:

2 Gergely Boros, Attila Mozsár (2015) Comparison of different methods used for phosphorus 3 determination in aquatic organisms. Hydrobiologia, Volume 758, Issue 1, pp 235-242. DOI 4 10.1007/s10750-015-2293-2

5

\section{Comparison of different methods used for phosphorus determination in aquatic}

organisms

\author{
Gergely Boros*, Attila Mozsár
}

Balaton Limnological Institute, MTA Centre for Ecological Research, P.O. Box 35, Tihany, H-8237 Hungary

*corresponding author: boros.gergely@okologia.mta.hu

Office telephone: +3687448 244/226; FAX: +36 87448006

\footnotetext{
Abstract

The reliable determination of the total phosphorus $(\mathrm{P})$ content stored in aquatic biota is essential for studies on nutrient stoichiometry, as well as for effective lake management measures. However, a variety of methods are found in the literature for sample P content determination, which renders it necessary to assess whether the data reported in different studies are comparable. We used different combinations of combustion durations, acid types and acid concentrations for sample digestion, and measured $\mathrm{P}$ concentrations subsequently with the standard colorimetric method. In addition, P contents of samples were assayed by ICP-OES and MP-AES methods. Our results confirmed that the variability among studies using different methods may explain some of the reported intraspecific and interspecific
} 
28 variation. We found that duration of combustion exerted the most important influence on the

29 P retrieval, while acid type and acidity of the hydrolysing solution did not substantially 30 influence the efficiency of sample digestion. We recommend using $8 \mathrm{~h}$ of combustion and 0.3

$31 \mathrm{~N} \mathrm{HCl}$ for acid hydrolysis prior to the colorimetric $\mathrm{P}$ analysis, and urge standardisation in the $32 \mathrm{P}$ analyses of biotic samples so as to obtain reliable results and data comparable among 33 different studies.

34

35 Key words: fish, benthic invertebrate, zooplankton, macrophyte, phosphorus, sample 36 digestion 


\section{Introduction}

Phosphorus (P) is a major biogenic element that often functions as a limiting nutrient in aquatic habitats, influencing primary production and ultimately total ecosystem production (Carpenter et al., 1992; Brönmark \& Hansson, 2005; Dodson, 2005; Sterner, 2008). All organisms sequester and use P to support structural (e.g., bone, phospholipid and nucleic acid formation) and functional (energy transfer) demands (Sterner \& Elser, 2002). However, the P content in different organisms is highly variable, being relatively low in freshwater plants (Kufel \& Kufel, 2002) and the highest in fish, compared to other members of the aquatic food webs (Tarvainen et al., 2002; Frost et al., 2006; Griffiths, 2006; Boros et al., 2009). In addition, the $\mathrm{P}$ sequestered in different organisms is tied up in various tissues and biochemicals that differentially resist physical and chemical degradation. For instance, softer tissues like muscles may decompose and release $\mathrm{P}$ shortly after death, while more recalcitrant materials such as bones and scales may retain a significant fraction of their P content over several months or years (Parmenter \& Lamarra, 1991; Claeson et al., 2006). This could have important implications for the dynamics of decomposition-derived internal $\mathrm{P}$ loading in aquatic ecosystems. In addition, and from another perspective, the presence and proportion of materials with low degradability in the bodies of aquatic organisms may determine the efficiency of whole body P content analyses.

The precise and reliable assessment of the total $\mathrm{P}$ content in different aquatic organisms is essential for effective and targeted lake management measures (e.g., when calculating P removal via fish or macrophyte harvesting), as well as for ecological stoichiometric analyses of aquatic food webs. However, in contrast to the more standardized carbon and nitrogen measurements - which are usually obtained by elemental analysers using the same protocol for assaying the chemical composition of samples - there are a variety of methods in the literature for $\mathrm{P}$ content determination, including 'traditional' (sample digestion and 
subsequent colorimetric P measurement) and more modern techniques (e.g., Inductively Coupled Plasma instruments). The common feature of the traditional measurements is the application of the ammonium molybdate method (Strickland \& Parsons, 1972) for the colorimetric (spectrophotometric) quantification of the orthophosphate ions liberated after various digestion procedures.

However, a number of different methods have been reported for sample digestion. They can be divided into two main categories; (1) wet digestion of samples in acidic media (e.g., Tanner et al., 1999; 2000; Boros et al., 2009; Vrede et al., 2011); and (2) combustion/incineration followed by acid hydrolysis/dissolution of the produced ash (e.g., Walve \& Larsson, 1999; Sterner \& George, 2000; El-Sabaawi et al., 2012). Moreover, for each digestion method, we can find numerous combinations of acid types, acid concentrations, and durations of heating or combustion. For example, Sterner \& George (2000) ashed fish samples at $500{ }^{\circ} \mathrm{C}$ for a minimum of $4 \mathrm{~h}$, and subsamples of ash were acid hydrolysed in $0.3 \mathrm{~N} \mathrm{HNO}_{3}$. Czamanski et al. (2011) followed a protocol similar to Sterner \& George (2000), and incinerated subsamples of whole fish homogenates and fish gut contents at $500{ }^{\circ} \mathrm{C}$ for $5 \mathrm{~h}$, then added $0.3 \mathrm{M} \mathrm{HNO}_{3}$ to the produced ash. In addition, samples were kept in tightly sealed vessels at a constant temperature of $80^{\circ} \mathrm{C}$ overnight. El-Sabaawi et al. (2012) also combusted fish samples at $500{ }^{\circ} \mathrm{C}$, but they used $\mathrm{HCl}$ solution for acid hydrolysis at 102 ${ }^{\circ} \mathrm{C}$ for $2 \mathrm{~h}$. In turn, Walve \& Larsson (1999) combusted zooplankton samples at $550{ }^{\circ} \mathrm{C}$ and used "persulphate solution" on a subset of their samples, and a mixture of $\mathrm{H}_{2} \mathrm{SO}_{4}, \mathrm{HNO}_{3}$ and $\mathrm{H}_{3} \mathrm{ClO}_{4}$, heated to $355{ }^{\circ} \mathrm{C}$, on some other zooplankton samples. Shearer (1984) also used incineration at $550{ }^{\circ} \mathrm{C}$ for fish samples, but the ash was dissolved in a mixture of equal parts of concentrated $\mathrm{HCl}$ and $\mathrm{HNO}_{3}$. Finally, Hendrixson et al. (2007) incinerated fish samples at $550{ }^{\circ} \mathrm{C}$ for $8 \mathrm{~h}$ and the produced ash was subsequently dissolved in $10 \mathrm{~N} \mathrm{H}_{2} \mathrm{SO}_{4}$. 
These few examples clearly demonstrate the diversity of methods used to analyse total P content of samples. It can be hypothesized that different methods vary in their efficiency in recovering P. This generates the question of whether the results of different studies on the body composition of the same species are comparable. The existing differences between studies in reported $\mathrm{P}$ contents (examples in Table 1) may be attributed to the natural intraspecific variability in elemental stoichiometry due to differences in the habitat, size, feeding habits, food quality or condition factor of the analysed individuals (e.g., Pilati \& Vanni, 2007; Boros et al., 2012; Benstead et al., 2014), but also to differing methods.

Based on the aforementioned variability in methodology and among reported $\% \mathrm{P}$ values,

we designed the current study to compare efficiencies of the most widely applied methods for $\mathrm{P}$ analysis of aquatic organisms, and to reveal the comparability of body $\mathrm{P}$ content data reported in different studies. In addition, our aim was to find a reliable method that is relatively fast and cost-effective, and hence, could serve as a standard for body $\mathrm{P}$ content analyses.

\section{Materials and Methods}

Samples and sample processing

To test the reliability and efficiency of different digestion methods used prior to Lepomis gibbosus Linnaeus, family Centrarchidae; and roach Rutilus rutilus Rafinesque,

107 Cyprinidae), benthic insect larvae (Diptera: Chironomidae), cladoceran zooplankton (Daphnia

108 sp.) and submerged macrophyte (hornwort Ceratophyllum demersum Linnaeus). In addition, samples of a standard reference material (pork muscle homogenate; NCS ZC 81001) with certified $0.813 \pm 0.031 \% \mathrm{P}$ content were analysed to validate the measurements and test the $\mathrm{P}$

111 recoverability for each method. 
Samples were dried to a constant weight at $60{ }^{\circ} \mathrm{C}$ and were ground to a fine powder with

113 a Retsch ZM 200 centrifugal mill. All samples (except the reference material) consisted of

114 homogenates of whole organisms. Hornwort, roach and pumpkinseed samples were collected

115 from the oligo-mesotrophic Lake Balaton (Hungary), while zooplankton and benthic

116 macroinvertebrate samples were obtained from stocks maintained as fish forage.

Sample analysis

Dried and pulverized subsamples $(10-15 \mathrm{mg})$ were ashed at $550{ }^{\circ} \mathrm{C}$ for three different glass vials after cooling. Consequently, we had 3 different variables (duration of combustion, acidity, and acid type) and 18 different treatments. Each treatment consisted of three replicates. After acid addition to the ashes, glass vials were capped tightly and stored at 105 Parsons, 1972) was the hundred-fold dilution of the cooled samples, resulting in a $10 \mathrm{ml}$ final sample volume $(0.1 \mathrm{ml}$ of the original solution $+9.9 \mathrm{ml}$ ultrapure 'Milli-Q' water). Phosphorus concentrations were measured with a Shimadzu UV 160-A spectrophotometer. We also examined the effect of diluted $0.3 \mathrm{~N}$ and $1 \mathrm{~N}$ digesting acids on the outcomes of colorimetric P analyses, because acidic media may affect the intensity of the blue colour

131 (proportional to the $\mathrm{P}$ concentration in samples) in some cases (Pai et al., 1990). To test this

132 effect, $10 \mathrm{ml}$ of each acid type $\left(0.3 \mathrm{~N}\right.$ and $1 \mathrm{~N}$ concentrations of $\mathrm{HCl}, \mathrm{HNO}_{3}$ or $\left.\mathrm{H}_{2} \mathrm{SO}_{4}\right)$ were 133 pipetted into separate glass tubes, and were heated at $105{ }^{\circ} \mathrm{C}$ for $1 \mathrm{~h}$ (identical to samples). 134 After cooling, a $0.1 \mathrm{ml}$ subsample was taken from each tube and P concentrations were set to $135300 \mu \mathrm{g} \mathrm{L}^{-1}$ in the final, $10 \mathrm{ml}$ volume samples by adding $9.9 \mathrm{ml}$ aqueous solution of $\mathrm{KH}_{2} \mathrm{PO}_{4}$.

136 This enabled us to see any potential deviations from the expected $300 \mu \mathrm{g} \mathrm{L}^{-1}$ concentration as 
137 a function of acidity. Moreover, blank (neutral pH) samples also with $300 \mu \mathrm{g} \mathrm{L^{-1 }} \mathrm{P}$

138 concentration, consisting of $\mathrm{KH}_{2} \mathrm{PO}_{4}$ dissolved in Milli-Q water and no acids were also 139 included.

140 In addition to colorimetric P content analyses, Inductively Coupled Plasma - Optical

141 Emission Spectrometry (Agilent ICP - OES 720) and Microwave Plasma - Atomic Emission

142 Spectrometry (Agilent MP - AES 4100) were used for P content determination on a subset of

143 all sample types. Before ICP-OES and MP-AES measurements, dried and homogenised 144 samples were processed with microwave digestion in Teflon vessels $(0.3 \mathrm{~g}$ dried sample $+\mathrm{a}$

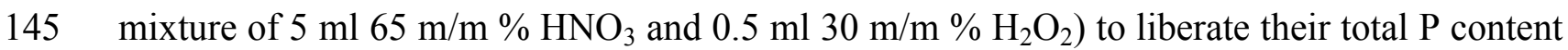
146 (Rodushkin et al., 1999; Fehér et al., 2013). The resulting solutions were diluted with 147 ultrapure 'Milli-Q' water prior to measurements.

\section{Statistical analyses}

To explore the effect of acidity on the results of colorimetric measurements, we used the

151 Dunnett test, wherein the concentrations measured in samples containing a mixture of 152 standard $\mathrm{P}$ solution and hundred-fold diluted $0.3 \mathrm{~N}$ or $1 \mathrm{~N}$ acids (see description above) were 153 compared to the concentrations measured in the blank samples.

154 The effects of combustion duration, concentration of hydrolysing solution and acid type 155 (included as factors in the models) on the efficiency of P recovery were tested with three-way 156 ANOVA. Subsequently, Tukey's honest significant difference (HSD) post-hoc tests were 157 used to reveal differences between treatments, in cases where the effect of any of the factors 158 proved to be significant $(\mathrm{p} \leq 0.05)$. Statistical analyses were performed with the StatSoft 159 Statistica 7.0 software. 
Comparison of the samples containing purely hundred-fold diluted $0.3 \mathrm{~N}$ and $1 \mathrm{~N}$ acids

164 and phosphate standard solution to the blanks showed no differences in the measurable $\mathrm{P}$ concentrations (Table 2). Accordingly, acidity of the diluted hydrolysing solutions was not found to influence the results of colorimetric measurements, which means that neutralisation

167 of samples could be omitted during analyses.

168 The positive effect of increased combustion duration on the measurable P concentrations 169 was obvious in all sample types, being the most pronounced in the case of pumpkinseed 170 samples (Fig. 1). Here, the difference between the lowest (2 h, $0.3 \mathrm{~N} \mathrm{HCl}$ treatment) and the 171 highest $(8 \mathrm{~h}, 1 \mathrm{~N} \mathrm{HCl}$ treatment) measured \% $\mathrm{P}$ values was more than $21 \%$. The second 172 largest difference $(18.2 \%)$ between the lowest $\left(2 \mathrm{~h}, 0.3 \mathrm{~N} \mathrm{H}_{2} \mathrm{SO}_{4}\right)$ and highest $(8 \mathrm{~h}, 1 \mathrm{~N}$ $\left.173 \mathrm{H}_{2} \mathrm{SO}_{4}\right) \% \mathrm{P}$ values occurred in roach samples. Moreover, for pumpkinseed, roach and 174 hornwort samples, there was virtually no overlap between the results obtained by colorimetric 175 methods (including all digesting treatments) and those by ICP-OES and MP-AES. In 176 contrast, there was considerable overlap between the results obtained by ICP-OES and 177 colorimetric measurements for benthic macroinvertebrates, zooplankton, and the reference 178 material. However, for all sample types, measurements with MP-AES produced consistently 179 lower \% P values than other methods.

180 ANOVA revealed that combustion duration was the only factor influencing the efficiency

181 of digestion for all samples types (Table 3). Acid concentration was significant only for 182 benthic macroinvertebrate samples, while the type of acid did not affect the efficiency of 183 digestion for any samples.

184 As combustion duration proved to be the most important factor in determining the $\mathrm{P}$ 185 yields from all sample types, the three different durations $(2 \mathrm{~h}, 4 \mathrm{~h}, 8 \mathrm{~h})$ were compared to 186 assess significant differences between treatments and the time interval that is required for 
187 effective sample digestion. We found that $2 \mathrm{~h}$ of combustion was not sufficient for the

188 efficient sample decomposition. In turn, $4 \mathrm{~h}$ of combustion was sufficient in the case of roach, 189 hornwort and reference material samples, while $8 \mathrm{~h}$ of incineration yielded significantly 190 higher P contents in pumpkinseed, benthic macroinvertebrate and zooplankton samples (Fig. $1912)$.

192

193

194

195

196

197

198

199

200

201

202

203

204

205

206

207

\section{Discussion}

Our results suggest that the reported among-study variation in $\mathrm{P}$ contents may be explained at least in part by methodological inconsistencies. It was found that the duration of combustion exerted the most important effect on sample decomposition and thus on the efficiency of P retrieval. Even though 2 hours of incineration prior to acid hydrolysis is not commonly used in P content determination of biotic samples, we decided to test the efficiency of this relatively short time interval, because we assumed that for some easily degradable sample types, 2 hours at $550{ }^{\circ} \mathrm{C}$ may be sufficient. This could save time and energy during analyses. However, our results show that samples must be combusted for at least 4 hours to obtain reliable results on $\mathrm{P}$ content. Nevertheless, using 8 hours of combustion was the most effective among the methods we compared. In contrast, acid type and the acidity of the hydrolysing solution did not influence the efficiency of digestion considerably, and consequently all of the acid combinations we used in this study are eligible for sample digestion and would be expected to produce comparable results. Moreover, the results highlight that if samples contain hundred-fold diluted $0.3 \mathrm{~N}$ or $1 \mathrm{~N}$ acids, neutralisation prior to colorimetric measurements is not necessary, which could accelerate and simplify the process of $\mathrm{P}$ content determination.

Different sample types contain recalcitrant components in different proportions, and the results suggest that 4 hours of incineration may not be able to degrade all particles and 
212 molecules that bind $\mathrm{P}$ in benthic insect, zooplankton and pumpkinseed samples. The 213 difference between roach and pumpkinseed in the duration necessary for effective 214 decomposition could be attributed to the different anatomy of the two species. The proportion 215 of bony matter is higher in the bodies of centrarchid fish (pumpkinseed), compared to 216 cyprinids (roach) (Hendrixson et al., 2007). Bones, scales and other hard structures store $73-$ $21788 \%$ of the total P content in teleost fish body (Rønsholdt, 1995; Hendrixson et al., 2007), 218 and these tissues resist rapid degradation under natural decomposition (Parmenter \& Lamarra, 219 1991; Claeson et al., 2006), and probably act as the most recalcitrant materials during 220 laboratory digestion as well. Likewise, for benthic macroinvertebrates and zooplankton, 8 221 hours of combustion yielded the highest $\mathrm{P}$ contents, most probably due to the presence of 222 recalcitrant materials such as $\mathrm{P}$ embedded in chitinous structures. It is assumable that $8 \mathrm{~h}$ of 223 combustion is sufficient for effective sample decomposition for all biotic samples, but further exploration is needed to verify this, including samples from a wide range of aquatic and terrestrial taxa.

Surprisingly, P contents assayed with ICP-OES, and particularly with MP-AES, were 227 typically lower than those obtained through colorimetric measurements. Thus, MP-AES is 228 likely to underestimate the actual $\mathrm{P}$ content in all sample types (except for the reference material), while ICP-OES measurements resulted in rather low P values in fish samples, but 230 not in benthic macroinvertebrates and zooplankton. We presume that the relatively low $\mathrm{P}$ 231 recoveries obtained with ICP and MP methods may be attributed to the lower efficiency of 232 sample digestion that was used prior to these measurements. However, we followed a 233 digestion protocol that is normally used before ICP and MP measurements (Rodushkin et al., 234 1999; Fehér et al., 2013). Moreover, the consistent differences between the results obtained by 235 ICP and MP methods may be the consequence of their dissimilar sensitivity in detecting P. 236 These results suggest that microwave digestion with acids in Teflon vessels is only 
moderately effective for some sample types, and this is especially true for fish samples, which

238 store most of their $\mathrm{P}$ in heavily recalcitrant bone and scale fragments. This finding draws 239 attention to the need for some refinement in the methodology of sample preparation used 240 before ICP and MP measurements.

Various methods for sample digestion prior to colorimetric $\mathrm{P}$ concentration determination can be found in the literature, including different combinations of incineration duration, acid concentration and acid type. We have established that acid type and acidity of the hydrolysing solution do not significantly affect the $\mathrm{P}$ recovery. Thus, we presume that $\% \mathrm{P}$ values reported for a particular species in different studies are comparable to each other, when different acids were used for sample acid hydrolysis. However, the use of variable combustion durations may render it difficult to compare the reported $\mathrm{P}$ contents in some cases. In fact, the differences 248 between $\mathrm{P}$ values obtained by different methods from the same species are comparable to the natural interspecific variations. For instance, Czamanski et al. (2011) established that farmed rainbow trout (Oncorhynchus mykiss Walbaum) have $1.3 \%$ body P content (in dry mass), while Hendrixson et al. (2007) reported $2.4 \% \mathrm{P}$ on the same species, collected from an 252 oligotrophic lake. These studies differed in their combustion duration: Czamanski et al. 253 (2011) used $5 \mathrm{~h}$ of combustion, while Hendrixson et al. (2007) incinerated samples for $8 \mathrm{~h}$. 254 Moreover, studies differed in the combustion temperature $\left(500\right.$ vs. $\left.550{ }^{\circ} \mathrm{C}\right)$ and in the acids 255 used for dissolving the produced ashes $\left(0.3 \mathrm{M} \mathrm{HNO}_{3}\right.$ vs. $\left.10 \mathrm{~N} \mathrm{H}_{2} \mathrm{SO}_{4}\right)$. We have to note that 256 farmed rainbow trout (Czamanski et al., 2011) had higher (56.7\%) body carbon content, 257 compared to wild-caught rainbow trout (47.5\%; Hendrixson et al., 2007), which might 258 contribute significantly to the remarkable differences in $\mathrm{P}$ contents, because any changes in 259 the proportion of carbon may drive ("dilute") the relative proportions of most other elements, 260 including P. However, the methodological dissimilarities may explain at least a fraction (8 $26110 \%$ ) of the among-study variation in $\% \mathrm{P}$ contents, which is also important. Thus, we suggest 
and urge the international standardisation in $\mathrm{P}$ content analyses of biotic samples, to eliminate variability that may arise from the various and in some cases unpredictable efficiency of different methods used for determining sample P contents.

\section{Conclusion}

We recommend using $8 \mathrm{~h}$ of incineration before acid hydrolysis of samples for $\mathrm{P}$ analysis, as this duration was proven to be the most effective among the methods we compared. Because there were no considerable differences between acids in their digesting efficiency, we suggest using $0.3 \mathrm{~N} \mathrm{HCl}$ for acid hydrolysis, as this method was the most cost-effective in our study. By implementing the same protocol during $\mathrm{P}$ analyses, results published by different authors would be more reliably comparable, thereby facilitating comparison of the actual variation in elemental composition arising from ecological and environmental factors.

\section{Acknowledgements}

The authors would like to thank M. J. Vanni, S. Palmer, S. Harangi, E. Baranyai, Z. Vital and Z. Poller for help with laboratory work and manuscript preparation. We acknowledge the contribution of Agilent Technologies and the Novo-Lab Ltd. (Hungary) for providing the ICP-OES 720 and the MP-AES 4100.

\section{References}

Benstead, J. P., J. M. Hood, N. V. Whelan, M. R. Kendrick, D. Nelson, A. F. Hanninen \& L. M. Demi, 2014. Coupling of dietary phosphorus and growth across diverse fish taxa: a metaanalysis of experimental aquaculture studies. Ecology 95: 2768-2777.

Boros, G., I. Tátrai \& S. A. Nagy, 2009. Using high-pressure Teflon bomb digestion in phosphorus determination of aquatic animals. International Journal of Limnology 45: 55-58. 
Boros, G., J. Jyväsjärvi, P. Takács, A. Mozsár, I. Tátrai, M. Søndergaard \& R. I. Jones, 2012. Between-lake variation in the elemental composition of roach (Rutilus rutilus L.). Aquatic Ecology 46: 385-394.

Brönmark, C. \& L. A. Hansson, 2005. The biology of lakes and ponds. Oxford University Press, Oxford.

Carpenter, S. R., K. L. Cottingham \& D. E. Schindler, 1992. Biotic feedbacks in lake phosphorus cycles. Trends in Ecology and Evolution 7: 332-336.

Claeson, S. M., J. L. Li, J. E. Compton \& P. A. Bisson, 2006. Response of nutrients, biofilm, and benthic insects to salmon carcass addition. Canadian Journal of Fisheries and Aquatic Sciences 63: 1230-1241.

Czamanski, M., A. Nugraha, P. Pondaven, M. Lasbleiz, A. Masson, N. Caroff, R. Bellail \& P. Tréguer, 2011. Carbon, nitrogen and phosphorus elemental stoichiometry in aquacultured and wild-caught fish and consequences for pelagic nutrient dynamics. Marine Biology 158: $2847-2862$.

Dodson, S. I., 2005. Introduction to limnology. McGraw Hill, New York.

El-Sabaawi, R. W., T. J. Kohler, E. Zandoná, J. Travis, M. C. Marshall, S. A. Thomas, D. N. Reznick, M. Walsh, J. F. Gilliam, C. Pringle \& A. S. Flecker, 2012. Environmental and Organismal Predictors of Intraspecific Variation in the Stoichiometry of a Neotropical Freshwater Fish. Plos One 7: 1-12.

Fehér, M., E. Baranyai, E.Simon, P. Bársony, I. Szücs, J. Posta \& L. Stündl, 2013. The interactive effect of cobalt enrichment in Artemia on the survival and larval growth of barramundi, Lates calcarifer. Aquaculture 414-415: 92-99. 
Frost, P. C., J. P. Benstead, W. F. Cross, H. Hillebrand, J. H. Larson, M. A. Xenopoulos \& T.

310 Yoshida, 2006. Threshold elemental ratios of carbon and phosphorus in aquatic consumers.

$311 \quad$ Ecology Letters 9: 774-779.

312 Griffiths, D., 2006. The direct contribution of fish to lake phosphorus cycles. Ecology of 313 Freshwater Fish 15: 86-95.

314 Hendrixson, H. A., R.W. Sterner \& A. D. Kay, 2007. Elemental stoichiometry of freshwater 315 fishes in relation to phylogeny, allometry and ecology. Journal of Fish Biology 70: 121-140.

316 Kufel, L. \& I. Kufel, 2002. Chara beds acting as nutrient sinks in shallow lakes - a review. 317 Aquatic Botany 72: 249-260.

318 Pai, S-C., C-C. Yang \& J. P. Riley, 1990. Effects of acidity and molybdate concentration on 319 the kinetics of the formation of the phosphoantimonylmolybdenum blue complex. Analitica 320 Chimica Acta 229: 115-120.

321 Parmenter, R. R. \& V. A. Lamarra, 1991. Nutrient cycling in a freshwater marsh-the decomposition of fish and waterfowl carrion. Limnology and Oceanography 36: 976-987.

Pilati, A. \& M. J. Vanni, 2007. Ontogeny, diet shifts, and nutrient stoichiometry in fish. Oikos 324 116: $1663-1674$.

325 Rodushkin, I., T. Ruth \& A. Huhtasaari, 1999. Comparison of two digestion methods for 326 elemental determinations in plant material by ICP techniques. Analytica Chimica Acta 378 : $327 \quad 191-200$.

328 Rønsholdt, B., 1995. Effect of size/age and feed composition on body composition and 329 phosphorus content of rainbow trout Oncorhynchus mykiss. Water Science and Technology 330 31: 175-183. 
331 Shearer, K. D., 1984. Changes in elemental composition of hatchery-reared rainbow trout, 332 Salmo gairdneri, associated with growth and reproduction. Canadian Journal of Fisheries 333 and Aquatic Sciences 41: 1592-1600.

334 Sterner, R. W. \& N. B. George, 2000. Carbon, nitrogen and phosphorus stoichiometry of 335 cyprinid fishes. Ecology 81: 127-140.

336 Sterner, R. W. \& J. J. Elser, 2002. Ecological stoichiometry: the biology of elements from 337 molecules to the biosphere. Princeton University Press, Princeton.

338 Sterner, R. W., 2008. On the phosphorus limitation paradigm for lakes. International Review 339 of Hydrobiology 93: 433-445.

340 Strickland, J. D. H. \& T. R. Parsons, 1972. A practical handbook of seawater analysis. 341 Fisheries Research Board of Canada, Ottawa.

342 Tanner, D. K., E. N. Leonard \& J. C. Brazner, 1999. Microwave digestion method for 343 phosphorus determination of fish tissue. Limnology and Oceanography 44: 708-709.

344 Tanner, D. K., J.C. Brazner \& V. J. Brady, 2000. Factors influencing carbon, nitrogen, and 345 phosphorus content of fish from a Lake Superior coastal wetland. Canadian Journal of $346 \quad$ Fisheries and Aquatic Sciences 57: 1243-1251.

347 Tarvainen, M., J. Sarvala \& H. Helminen, 2002. The role of phosphorus release by roach 348 (Rutilus rutilus L.) in the water quality changes of a biomanipulated lake. Freshwater 349 Biology 47: 2325-2336.

350 Vrede, T, S. Drakare, P. Eklöv, A. Hein, A. Liess, J. Olsson, J. Persson, M. Quevedo, R. 351 Stabo \& R. Svenback, 2011. Ecological stoichiometry of Eurasian perch-intraspecific 352 variation due to size, habitat and diet. Oikos 120: 886-896. 
353 Walve, J. \& U. Larsson, 1999. Carbon, nitrogen and phosphorus stoichiometry of crustacean 354 zooplankton in the Baltic Sea: implications for nutrient recycling. Journal of Plankton $355 \quad$ Research 21: 2309-2321.

356

357 


\begin{tabular}{lcc}
\multicolumn{1}{c}{ Species } & *Reported \% P content & Reference \\
\hline Rainbow trout (Oncorhynchus mykiss W.) & 1.3 & Czamanski et al., 2011 \\
Brown bullhead (Ameiurus nebulosus L.) & $2.4 \pm 0.4$ & Hendrixson et al., 2007 \\
Northern pike (Esox lucius L.) & $2.6 \pm 0.6$ & Tanner et al., 2000 \\
& $3.4 \pm 0.4$ & Hendrixson et al., 2007 \\
Golden shiner (Notemigonus crysoleucas M.) & $2.1 \pm 0.3$ & Tanner et al., 2000 \\
& $3.5 \pm 0.2$ & Hendrixson et al., 2007 \\
& $3.5 \pm 0.3$ & Hendrixson et al., 2007
\end{tabular}

*Mean $\% \mathrm{P}$ values in dry mass $\pm \mathrm{SD}$ (where available) variability between studies, in which different methods were used for assaying the $\mathrm{P}$ content of samples, is illustrated. 


\begin{tabular}{|c|c|c|c|c|c|c|c|c|c|c|c|}
\hline \multicolumn{2}{|c|}{$\mathrm{HCl} 0.3 \mathrm{~N}$} & \multicolumn{2}{|c|}{$\mathrm{HCl} 1 \mathrm{~N}$} & \multicolumn{2}{|c|}{$\mathrm{HNO}_{3} 0.3 \mathrm{~N}$} & \multicolumn{2}{|c|}{$\mathrm{HNO}_{3} 1 \mathrm{~N}$} & \multicolumn{2}{|c|}{$\mathrm{H}_{2} \mathrm{SO}_{4} 0.3 \mathrm{~N}$} & \multicolumn{2}{|c|}{$\mathrm{H}_{2} \mathrm{SO}_{4} 1 \mathrm{~N}$} \\
\hline$\%$ & $\mathrm{p}$ & $\%$ & $\mathrm{p}$ & $\%$ & $\mathrm{p}$ & $\%$ & $\mathrm{p}$ & $\%$ & $\mathrm{p}$ & $\%$ & $\mathrm{p}$ \\
\hline 99.62 & 0.219 & 99.82 & 0.851 & 99.56 & 0.154 & 99.79 & 0.765 & 100.08 & 0.958 & 100.11 & 0.987 \\
\hline
\end{tabular}

373

374 Table 2: Comparison of the $\mathrm{P}$ concentrations measured in diluted acid solutions and blank

375 samples, revealing no significant differences. Percentages indicate the recoverability of P

376 concentration measured in the blanks, while " $p$ " denotes the significance of difference

377 between P contents measured in the acid solutions and blanks.

378

379

380

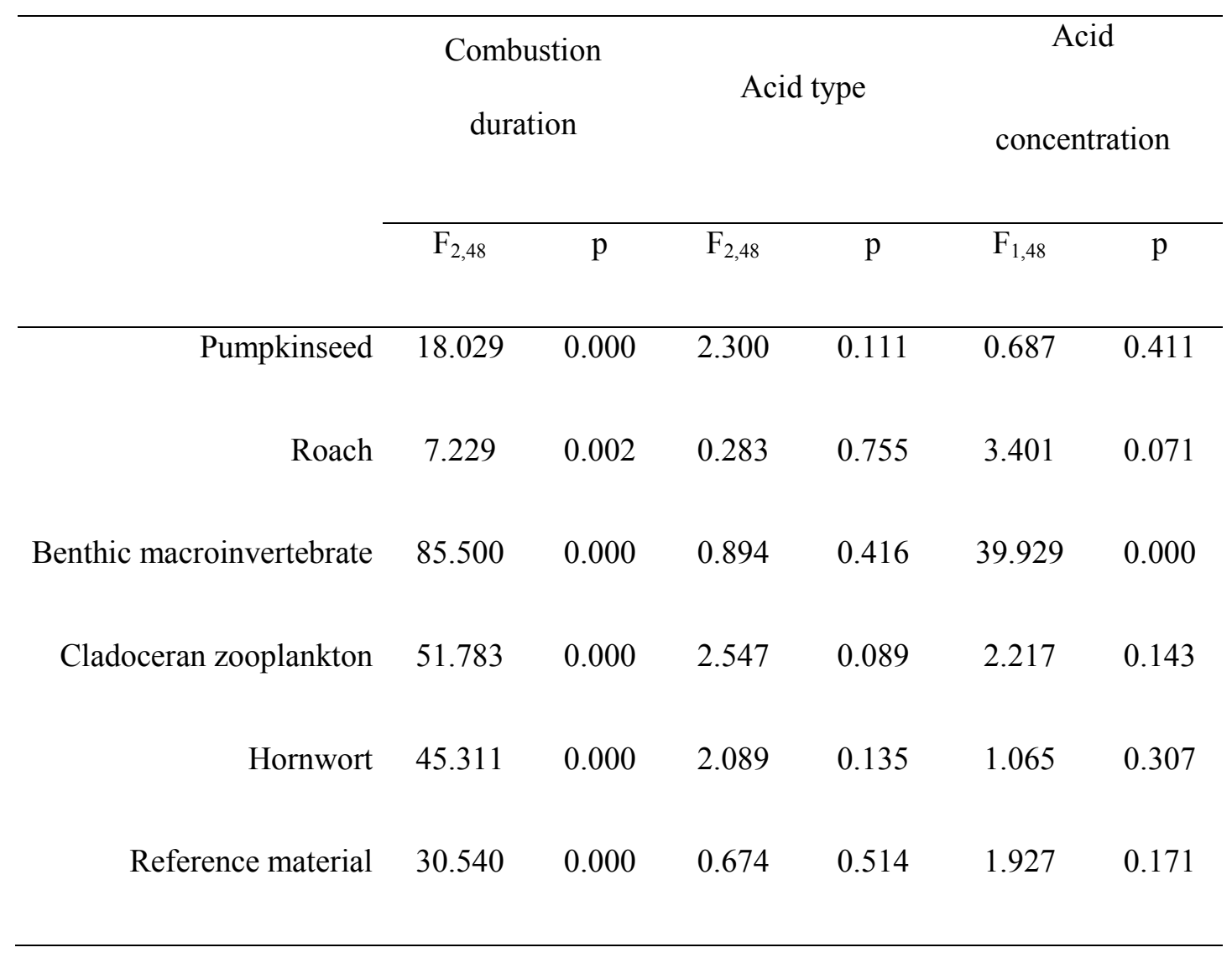


Table 3: The effect of the three factors (combustion duration, acid type and acid concentration) on P recovery. The ANOVA showed that combustion duration was the only

384 significant factor, whereas the effects of acid type and acidity of the hydrolysing solution were not significant (except in the case of acid concentration for benthic macroinvertebrates).

\section{Figure captions}

Fig. 1: Various $\mathrm{P}$ recoveries as a function of combustion duration, acid type and acid 391 concentration for the different sample types. Each point represents average \pm SD values. 392 Dashed lines: the P concentration assayed with ICP-OES; dotted lines: the P concentration 393 assayed with MP-AES; continuous line (last plot): the certified value (CV) of the reference 394 material

Fig. 2: Efficiencies of different combustion durations ( $2 \mathrm{~h}, 4 \mathrm{~h}, 8 \mathrm{~h})$ in recovering the $\mathrm{P}$ 397 content from various sample types. Lower case letters above the boxes denote the 398 similarity/difference of treatments (treatments denoted with the same letter do not differ 399 significantly; $p \geq 0.05$ ) 

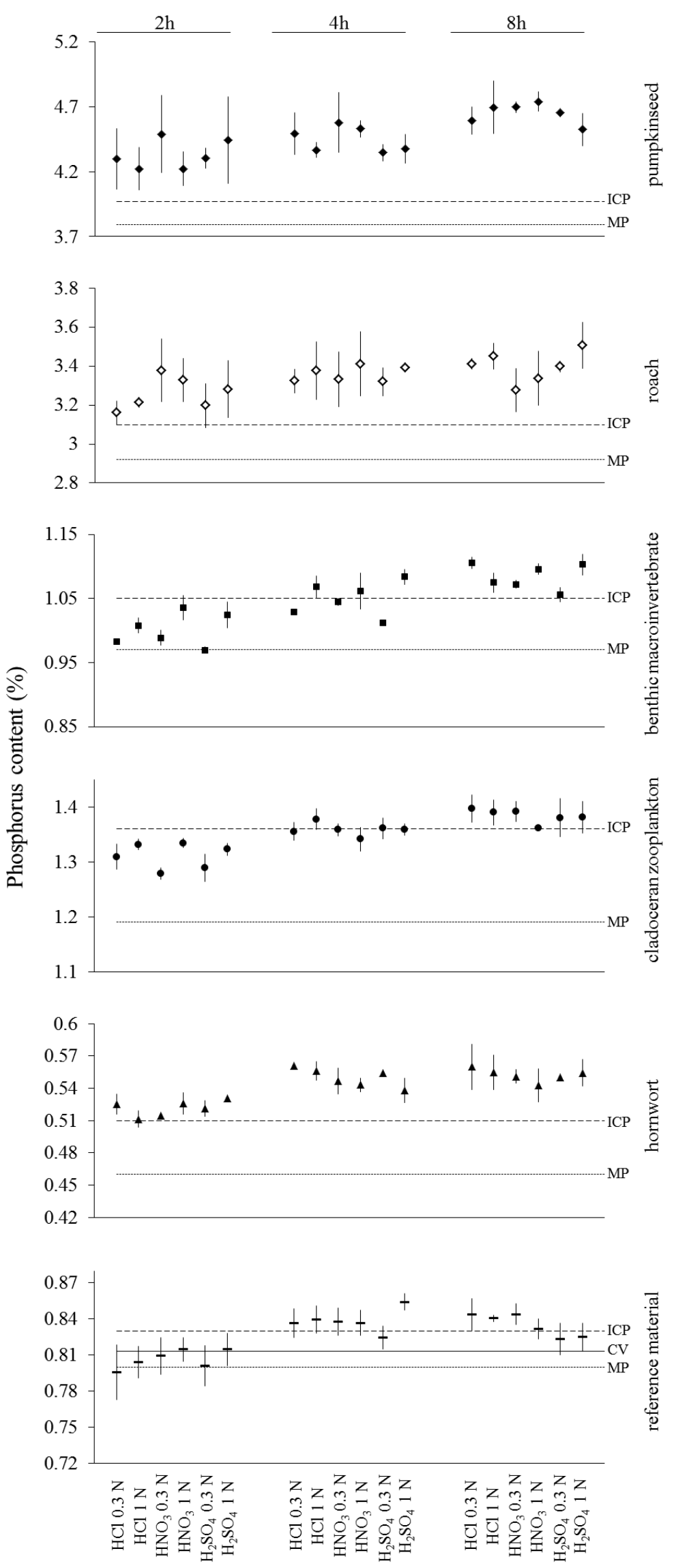

Fig. 1 

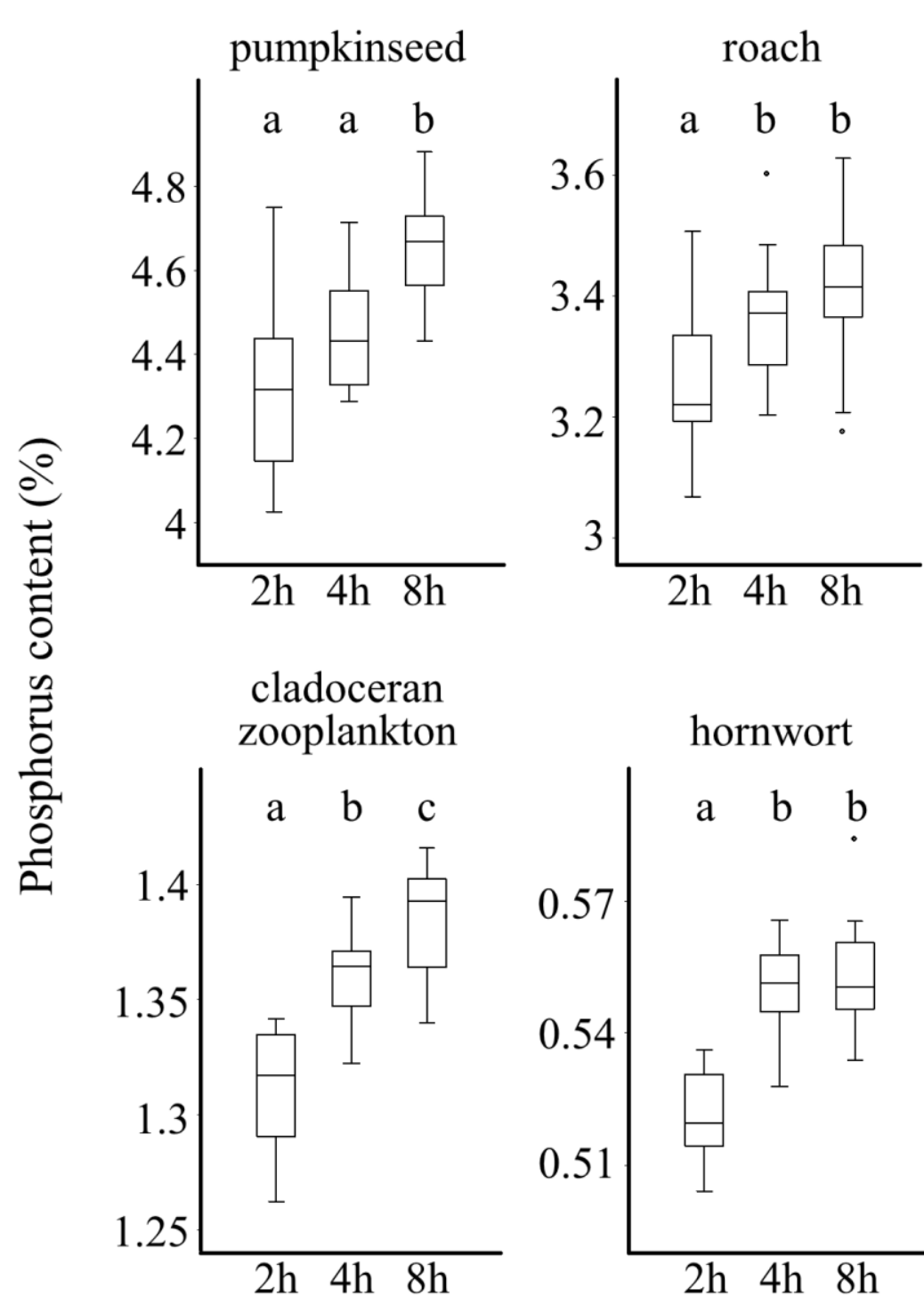

benthic

macroinvertebrate

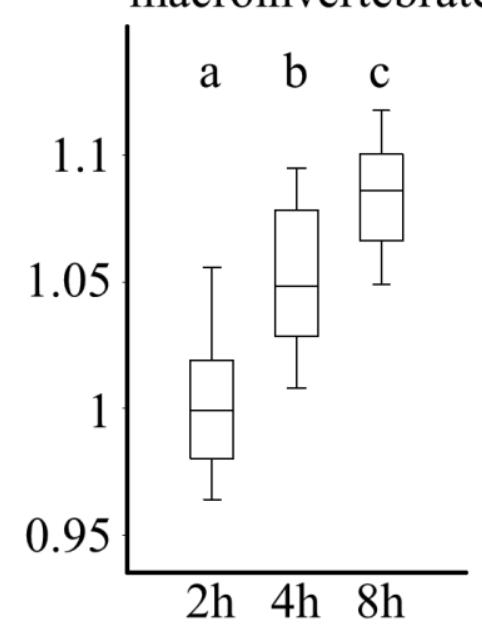

403

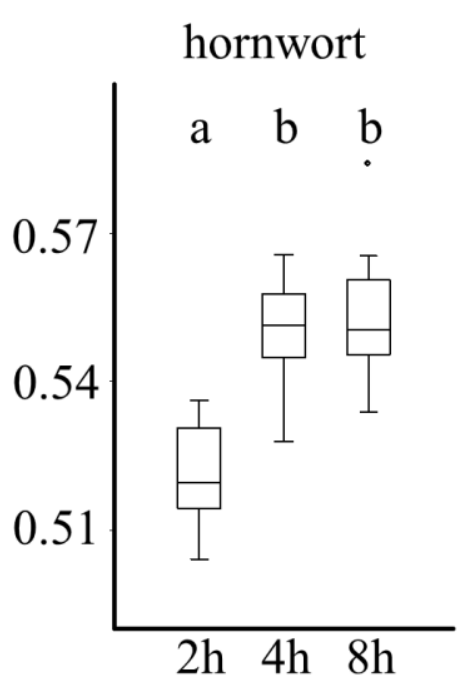

reference material

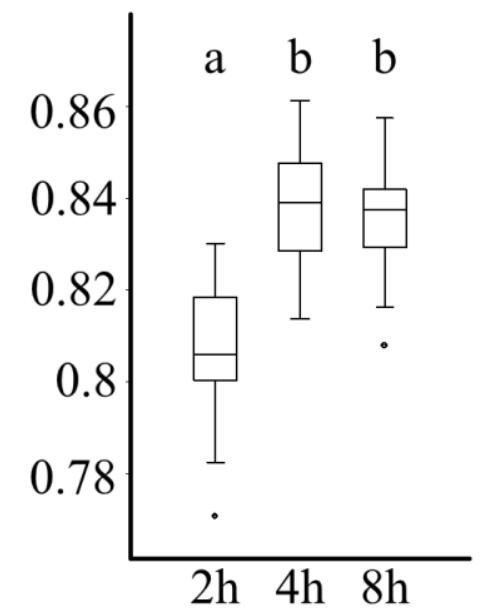

404

Fig. 2

405 